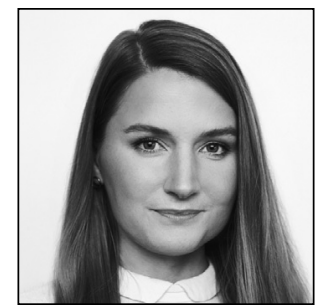

Kristiina Koll

\title{
Qualification of Consumer Contracts for the Supply of Digital Services under Estonian Law
}

\section{Introduction}

On 1 January 2022, the harmonised rules of the new EU Digital Content Directive ${ }^{*_{2}}$ (hereinafter referred to as 'the Directive') will become applicable. This Directive is unique among EU contract law directives in that it is not just applicable to a single type of contract but, rather, to all contracts between consumers and traders for the supply of digital content or digital services ${ }^{*}{ }^{3}$ where consumers pay a price or provide personal data. According to its Recital 12, the Directive does not determine the legal nature of contracts for the supply of digital content or digital services, and the question of whether such contracts constitute, for instance, a sales, service, rental, or sui generis contract is left to national law. It was a conscious choice not to qualify the legal nature of contracts in the Directive, ${ }^{*}$ with the broad scope of application intended to allow for rules that are technology-neutral, future-proof ${ }^{*}$, and difficult to circumvent. ${ }^{* 6}$

While the Directive provides for overarching regulation and does not differentiate among particular types of contracts, digital content or digital services are supplied under a specific contract, in practice. The legal nature of these contracts under Estonian law must be identified since the Directive regulates only

1 The research leading to this article was supported by the Estonian Research Council's grant PRG124.

2 Directive (EU) 2019/770 of the European Parliament and of the Council on certain aspects concerning contracts for the supply of digital content and digital services.

3 According to art 2 point 1, 'digital content' means data that are produced and supplied in digital form. According to art 2 point 2, a 'digital service' is a service that allows the consumer to create, process, store, or access data in digital form or allows the sharing of or any other interaction with data in digital form uploaded or created by the consumer or other users of that service.

4 K Sein and G Spindler, 'The New Directive on Contracts for the Supply of Digital Content and Digital Services - Scope of Application and Trader's Obligation to Supply - Part 1' [2019] 15(3) European Review of Contract Law 260. - DOI: https:// doi.org/10.1515/ercl-2019-0016; D Staudenmayer, 'Die Richtlinien zu den digitalen Verträgen' [2019] Zeitschrift für Europäisches Privatrecht 663, 668.

5 Recital 10 of the Directive, Commission proposal COM(2015) 634 final 11. Commission Staff Working Document Impact Assessment Accompanying the document Proposals for Directives of the European Parliament and of the Council (1) on certain aspects concerning contracts for the supply of digital content and (2) on certain aspects concerning contracts for the online and other distance sales of goods 46; J Vanherpe, 'White Smoke, but Smoke Nonetheless: Some (Burning) Questions Regarding the Directives on Sale of Goods and Supply of Digital Content' [2020] (2) European Review of Private Law 255.

6 D Staudenmayer, 'Auf dem Weg zum digitalen Privatrecht - Verträge über digitale Inhalte' [2019] NJW 2497. 
certain aspects of contract law. The remainder of the contractual relationship is determined by national law, such as that addressing the obligations of consumers and the legal remedies available to traders, ${ }^{*} 7$ and these rules may differ on the basis of the contract type involved. More broadly, this distinction is important for an understanding of how the Directive ties in with Estonian law and how pre-existing rules function in conjunction with the rules set forth in the Directive.

The aim behind this article is to analyse how contracts for the supply of digital content or digital services can be qualified under Estonian law. The more specific focus of the piece is on contracts for digital services: whereas it is not significantly problematic or controversial to consider a contract for the supply of digital content as a sales contract ${ }^{*}$, the distinction becomes more complicated where digital services are offered over the Internet, as in the case of storage in a cloud service (e.g. OneDrive ${ }^{*} 9$ or Dropbox ${ }^{* 10}$ ) or use of Webbased software (e.g. Microsoft Office $365^{* 11}$ ). It is not entirely clear whether the underlying contracts should be qualified as some type of contract for use (kasutusleping) or, instead, some type of contract for provision of services (teenuse osutamise leping) ${ }^{* 12}$.

Among contracts for use, contracts for the supply of digital content and digital services could be considered either as a lease contract (üürileping) or as a usufructuary lease contract (rendileping). As for contracts for provision of services, the supply of digital content and digital services might be qualified as falling under either a contract for work (töövõtuleping) or a contract for services (käsundusleping) ${ }^{*}{ }^{13}$.

The article examines the characteristics distinctive of these different types of contract, such as the possible object of the specific type of contract involved and the main obligations of the parties, to ascertain whether they are suitable for the supply of digital services. The analysis is anchored in a comparison of Estonian and German law.

\section{The object of a contract for the supply of digital services}

\subsection{The object of a contract for use}

Pursuant to Section 271 of the Law of Obligations Act (hereinafter LOA) ${ }^{* 14}$, the object of a lease contract must be a thing ${ }^{*}{ }^{15}$ - i.e. a corporeal object in the sense of Subsection 49(1) of the General Part of the Civil Code Act (hereinafter GPCCA) ${ }^{* 16}$. Neither digital content nor digital services are themselves things. Therefore, the supply of digital content or of digital services may be regarded as the object of a lease contract only if the digital content is stored on or the service is linked to, some medium that meets the requirements for classification as a thing. For example, this is the case where the consumer visits a video store and leases

Sein and Spindler (n 4) 260.

8 Pursuant to sub-s 208(3) LOA, the object of a sales contract can be, in addition to things, also rights and other objects, which may include digital content. German law takes the same approach. Under s 453 BGB, the provisions for the purchase of things apply, with the necessary modifications, to the purchase of rights and other objects. The possibility of selling digital content has been recognised also by P Kalamees and others, Lepinguõigus (Juura 2017) 28; M Käerdi and S Kärson in P Varul and others (eds), Võlaõigusseadus II, Kommenteeritud Väljaanne (Juura 2019) 42. For references related to German law, see, for example, F Faust in W Hau and R Poseck (eds), Beck'scher Online Kommentar, on BGB s 453, marginal note 24; C Berger in R Stürner (ed), Jauernig Bürgerliches Gesetzbuch Kommentar, on BGB s 453, marginal note 11. A sales contract is possible foremost where content is provided in a single act of supply or a series of individual acts of supply, such as when a video file is downloaded or a new e-magazine is provided to the consumer each month.

9 A description of the services offered under the OneDrive brand is available online at <www.microsoft.com/en/microsoft-365/ onedrive/online-cloud-storage > accessed 28 February 2021.

10 A description of the Dropbox services can be found at <www.dropbox.com/individual?cid=f88a8ef732099541d96f30491c 25a82fL $>$ accessed 28 February 2021.

11 Various possibilities exist for using Microsoft Office online, detailed at <www.microsoft.com/en/microsoft-365/buy/compareall-microsoft-365-products?market=af\#> accessed 28 February 2021. The Web-based service referred to in the article is a yearly subscription.

12 Microsoft Office 365 is used as an example for the possible qualification of contracts also by Sein and Spindler (n 4) 260.

13 It is important also to note that, since the object of a contract for the supply of digital content or digital services is usually protected by copyright, a licensing agreement too must be concluded with the consumer for use of the digital content or service. This contract is concluded in parallel with the contract for the supply of digital content or digital services. See G Lepik in Võlaõigusseadus II, Kommenteeritud Väljaanne (n 8) 465; Kalamees and others (n 8) 256.

14 RT I 2001, 81, 487; RT I, 04.01.2021, 19.

15 K Paal in Võlaõigusseadus II, Kommenteeritud Väljaanne (n 8) 237, 239.

16 RT I 2002, 35, 216, RT I, 23.05.2020, 4. 
a DVD or CD, which are things in the meaning of the GPCCA and are used to store a film, series, etc., which are digital content in the meaning of the Directive. However, this business model is no longer commonplace. With digital services such as the provision of cloud services and software-as-a-service contracts, the consumer can use the cloud or software but, in the strict sense, does not use a thing as such.

In Germany, several authors have affirmed that the rules of lease agreements should apply in relation to digital content and services. For example, Grünberger points out that both lease and usufructuary lease agreements are classic ways to allow for the temporary use of a thing. ${ }^{*} 7$ Schmidt-Kessel is of the same view and agrees that it is possible to allow someone to use digital content for a limited time. This is normally the situation seen under the software-as-a-service model, wherein the digital content that is the object of the contract is typically stored in the cloud. In both cases, the consumer is granted only the opportunity of using the digital content for the agreed period of time. ${ }^{* 18}$ Metzger holds that the rules applicable to lease contracts may be applied where the supply is of long duration and/or a price is paid periodically. ${ }^{* 19}$ In their articles on digital content and services, these authors do not, however, address how lease-contract rules might be applicable where no tangible object is supplied to the consumer. It is also worthy of note that the draft law $^{*}{ }^{20}$ for transposing the Directive into German law, by amending the German Civil Code (Bürgerliches Gesetzbuch, hereinafter BGB) ${ }^{*} 21$ through the addition of a Section 548 a, contains a proposal clearly stating that the rules applicable to lease agreements are applicable for the leasing of digital products.

The rationale for this solution can be found in the practice of the German courts. Already in 2007, the German Federal Court of Justice (Bundesgerichtshof, hereinafter BGH) held that an application-serviceproviding (hereinafter ASP) ${ }^{* 22}$ contract is to be considered a lease agreement for the use of Web-based software over a specific span of time. As for the requirement that the object of a lease agreement be a thing, the BGH held that it suffices for the software to be stored on some medium (dass das Computerprogramm auf einem Datenträger verkörpert ist); in this case, it was stored on the provider's server ${ }^{*}{ }^{23}$.

When one considers that the definition of a lease agreement is, in essence, the same under Estonian and German law ${ }^{* 24}$, as they both regulate the use of a thing, the question arises of whether the same conclusion could be drawn under Estonian law.

In principle, using any digital environment or software over the Internet requires some sort of physical basis. Storing digital content in a cloud environment depends on it being stored somewhere on a server that physically exists. This is why German authors have found that specific physical resources are designated for virtual components; this setting fulfils the condition that the object be a corporeal thing. ${ }^{*}{ }^{25}$ That view is not without its critics, though, since use of specific hardware or software has no meaning if the physical computer resources involved are presented only virtually. ${ }^{* 26}$ Accordingly, it would be more correct to say

17 M Grünberger, 'Verträge über digitale Güter' (2018) 218 Archiv für die civilistische Praxis (AcP) 213, 237. - DOI: https:// doi.org/10.1628/acp-2018-0011.

18 M Schmidt-Kessel and others, 'Fokus. Die Richtlinienvorschläge der Kommission zu Digitalen Inhalten und Online-Handel Teil 2' [2016] (2) Zeitschrift für das Privatrecht der Europäischen Union 54, 62. - DOI: https://doi.org/10.9785/gpr-20160204.

19 A Metzger, 'Verträge über digitale Inhalte und digitale Dienstleistungen: Neuer BGB-Vertragstypus oder punktuelle Reform?' (2019) 12 (74) Juristen Zeitung, 578.

20 'Referentenentwurf eines Gesetzes zur Umsetzung der Richtlinie über bestimmte vertragsrechtliche Aspekte der Bereitstellung digitaler Inhalte und digitaler Dienstleistungen' BGB s 548a. Available online at <www.bmjv.de/SharedDocs/Gesetzgebungsverfahren/DE/Bereitsstellung_digitaler_Inhalte.html> accessed 28 February 2021.

21 'Bürgerliches Gesetzbuch in der Fassung der Bekanntmachung vom 2. Januar 2002' (BGBl. I S. 42, 2909; 2003 I S. 738), with the most recent amendments having been made pursuant to art 13 of the law published on 22 December 2020 (BGBl. I S. 3256) available in German at <www.gesetze-im-internet.de/bgb/BJNR001950896.html\# BJNR001950896BJNG000102377> accessed 28 February 2021.

22 Used for offering Web-based software services.

23 [2007] NJW 2394, 'BGH: Rechtsnatur der Softwareüberlassung im Rahmen eines ASP-Vertrags'.

24 The definition of a lease contract is set out in s 535 of the BGB, which refers to the leased property (die Mietsache in German). The commentary on the LOA cites that section of law as one source of inspiration for s 271 of the LOA. See Võlaõigusseadus II, Kommenteeritud Väljaanne (n 8) 237.

25 In German, werden die virtuellen Komponenten einer physischen Ressource zugeordnet, sodass die Voraussetzungen der Körperlichkeit der Sache letztlich erfüllt sind. 'Bericht der Arbeitsgruppe „Digitaler Neustart“' (presented at Der Konferenz der Justizministerinnen und Justizminister der Länder 2017) 142 <www.justiz.nrw.de/JM/schwerpunkte/digitaler_neustart/zt_bericht_arbeitsgruppe/bericht_ag_dig_neustart.pdf> accessed 28 February 2021.

26 S Kirn and C Müller-Hengstenberg, 'Überfordert die digitale Welt der Industrie 4.0 die Vertragstypen Des BGB?' [2017] NJW 433, 435. 
that the rules applicable to lease contracts are applied to software irrespective of the fact that software is not a thing. ${ }^{*} 27$

I am among those who are rather sceptical in this regard. Even if there is a physical medium somewhere in the real, physical world where the digital content is stored, no thing is supplied to the consumer. The consumer receives digital content or a digital service only virtually. It is, therefore, questionable whether under a lease contract the connection to use of an actual physical thing could be so remote. In such a case, the benefit received by the consumer is not the use of a thing ${ }^{{ }^{2} 28}$, and neither is the object of the contract a thing.

Another contract for use regulated in the LOA that might be suited to the supply of digital services is the usufructuary lease contract as defined in Section 339 of the LOA. Since the object of a usufructuary lease contract can be any object (not restricted to a thing) in the meaning of Section 48 GPCCA, one thus can overcome the initial problem that arises when qualifying contracts for the supply of digital content or digital services as lease contracts. At the same time, according to Section 339 LOA, the object of a usufructuary lease contract must be an object that gives rise to fruit. ${ }^{*}{ }^{29}$ Similarly, it has been held in the German literature that the possibility of receiving fruit is the distinguishing characteristic for the legal qualification of a contract; this element cannot be excluded without the contract losing its primary legal nature. ${ }^{*} 30$

Since, as demonstrated above, the object of a contract for the supply of digital content or services is not normally a thing, the possibility of receiving civil fruit may arise. Under Subsection 62(3) GPCCA, 'civil fruit' means income that an entitled person receives from a right pursuant to the purpose of the right, and income received from the right arising from a legal relationship. When we examine the use of a cloud service such as OneDrive or Dropbox, it is evident that the consumer does not receive anything that could be qualified as fruit. The same conclusion holds true for software-as-a-service models such as that behind Microsoft 365 for the Web. When using the service, the consumer receives the advantages of use, but it cannot be said (at least in general terms) that doing so constitutes receipt of fruits. Qualifying such contracts as usufructuary lease contracts is therefore problematic. And, indeed, German authors have not qualified contracts for the supply of digital content as usufructuary lease contracts. Neither are there any references to usufructuary lease contracts in the German draft law for transposing the Directive.

Even if one were to construct hypothetical cases wherein the receipt of fruit could be imagined (e.g. income from blog posts ${ }^{*}{ }^{31}$ ), the wording of Section 339 LOA refers to fruit as something received from the object of the usufructuary lease contract under the rules of regular management. Whether a person can be considered a consumer if earning income in his own right from using a digital application is debatable. This is important because the scope of the Directive is limited to contracts between traders and consumers ${ }^{*} 32$, so a contract whose other party is not a consumer would fall beyond the scope of the rules in question.

\subsection{The object of a contract for provision of services}

Under a contract for work as provided for by Section $635 \mathrm{LOA}$, the contractor undertakes to manufacture or modify a thing or to achieve some other agreed result by providing a service (work). The object of the contract is achieving some result or progress. ${ }^{*} 33$ Contracts for work are characterised by a great variety of ways in which the contract may be performed. For example, the object might be intangible work (e.g. conducting an analysis, mounting a theatre production, or providing transportation) ${ }^{*} 34$; accordingly, it is possible to be

27 T Heydn, 'Software as a Service (SaaS): Probleme und Vertragsgestaltung' MMR, 7 (2020) 437.

28 It should be noted also that the consumer would not receive possession of the thing in this case because the server might be located in another country, halfway around the world. While s 271 LOA mentions not transfer of possession of a thing but, rather, granting use of a thing - and these two cannot be considered to be exactly the same - the rules governing lease contracts nevertheless contain provisions that refer to possession (see ss 291 and $334 \mathrm{LOA}$ ). Also, in practice, under a lease contract, possession of the thing too is transferred in most cases.

29 Kalamees and others (n 8) 227; Varul and others, Võlaõigusseadus II, Kommenteeritud Väljaanne (n 8) 381.

30 J D Harke in FJ Säcker and others (eds), Münchener Kommentar Zum BGB 8. Auflage (2020) on BGB s 581, marginal note 3.

31 K Saarmann, 'Digisisu lepingutingimustele vastavus direktiivi 2019/770 järgi ja vastavuskriteeriumite ülevõtmine Eesti õigusesse' (master's thesis, University of Tartu 2020) 22.

32 See art 3(1) of said directive.

33 This is true also under German law. See $\mathrm{J}$ Busche in Münchener Kommentar Zum BGB (n 30) s 631, marginal note 1.

34 On Germany, see Busche (n 33) s 631, marginal note 2; the same is true with regard to Estonia, per Varul and others, Võlaõigusseadus III Kommenteeritud Väljaanne (Juura 2009) 38. 
obliged to deliver non-corporeal results. ${ }^{*} 35$ For this reason, supply of digital content or digital services can be the object of a contract for work, and no similar problems arise with regard to the object of the contract as in the case of lease contracts.

In addition to contracts for work, some contracts for supply of digital services may be qualified as contracts for services under Section 619 LOA. The object of a contract for services is performance of a particular activity - i.e. the provision of a service as a process. ${ }^{*}{ }^{6}$ If a specific result is not achieved but the service provider has performed all obligations as required and has done all that is reasonably possible in pursuit of the specified result, there is no breach of the contract. ${ }^{*} 3$

In the German literature, Grünberger has concluded with regard to digital content and digital services that the supply of digital services can primarily be qualified as a contract for work where achievement of a result is important. ${ }^{*}{ }^{8}$ Likewise, Schmidt-Kessel has stated an opinion with regard to the supply of various services that under German law these are best qualified as contracts for work, and he has cited streaming services and social media as examples. ${ }^{*} 39$ The same approach is found in the draft law to transpose the Directive in Germany, which features a proposal to amend Section 650 BGB by specifying that the application of rules for contracts for work extends to digital products, so that these rules encompass the supply of digital content and digital services. ${ }^{*} 40$

I tend to agree that, while the supply of digital services would be possible under a contract for services or some similar form of contract ${ }^{*}$, most digital services are directed toward a particular result. Also, cloud services and software-as-a-service applications, which are the focus of this article, are result-oriented. The consumer has the expectation that his photos and documents stored in iCloud, Dropbox, etc. will continue to be stored there and remain available to him from there or proceeds from the understanding that he will be able to use the relevant Web-based software under the agreed conditions at any time. What is important is the specific result in the form of ability to use the cloud entity or software, not that the trader makes his best effort toward this end. If there is no possibility of using the cloud service, breach of contract has occurred. ${ }^{* 2}$ Hence, it would be conceivable to treat contracts of this nature as contracts for work.

If, then, these contracts are qualified as contracts for work, a question arises as to the degree to which the achievement of the desired result is under in the control of the obliged party. ${ }^{*} 43$ In practice, there is generally some third party between the consumer and the trader, such as an Internet service provider, whose actions determine whether the service reaches the consumer. Bearing this in mind, Article 5(2) of the Directive obliges the trader to ensure that any means suitable for accessing or downloading the digital content be made available or accessible to the consumer (such as a link) or that the digital service has been made available or accessible to a physical or virtual facility chosen by the consumer for that purpose. According to the Directive, this is sufficient for regarding the obligation of the trader to supply the service as fulfilled. ${ }^{*} 44$ In my opinion, in the context of a contract for work, one should interpret these terms to mean that the trader has to perform the obligations that are under the control of the trader in such a way that the possibility of achieving the specific result is guaranteed. The provisions of Article 5(2) limit the obligations of the trader such that the actions of any third parties are separate from them. That is, if any problems caused by a third party (e.g. with the consumer's Internet connection) are resolved, achievement of the specific result is ensured.

35 H-P Mansel in Jauernig Bürgerliches Gesetzbuch Kommentar (n 8) s 631 (preliminary remark), marginal note 2.

36 P Varul in Võlaõigusseadus III Kommenteeritud Väljaanne (n 34) 1,35.

P Varul in Võlaõigusseadus III Kommenteeritud Väljaanne (n 34) 4.

Grünberger (n 17) 237.

Schmidt-Kessel and others (n 18) 62.

40 'Referentenentwurf eines Gesetzes zur Umsetzung der Richtlinie über bestimmte vertragsrechtliche Aspekte der Bereitstellung digitaler Inhalte und digitaler Dienstleistungen’ (n 20) BGB s 650.

41 One example would be using the services of Airbnb or Booking.com wherein the trader performs the contract by selecting appropriate offers and showing them to the consumer and cannot guarantee a result in the form of the most suitable hotel or accommodation.

42 Other examples can be presented on the basis of the same logic. For example, a trader offering digital television or a streaming service has to ensure access to the films or television programmes. The trader must, in the case of Web-based messaging applications, ensure that the consumer can send messages to and receive messages from other consumers or, in relation to a Web-based game, has to ensure that the consumer can actually play the game. It is not enough that the trader act with care in pursuit of these objectives.

43 W Voit in Beck'scher Online Kommentar (n 8) on BGB s 631, marginal note 6.

44 Recital 41. 


\subsection{Interim conclusions}

From the standpoint of the object of the contract, qualifying contracts for the supply of digital services as lease contracts under Estonian law is problematic because the object of a lease contract must be a thing, a corporeal object. In the case of a usufructuary lease, the object of the contract may be an incorporeal object, but obtaining fruit from the use of the digital service is seldom possible.

As to the different contracts for the provision of services, the object of the contract does not pose similar problems. Digital content and services can be the object of a contract for the provision of services under Estonian law. In most cases, the orientation toward achieving a specific result leads to qualifying such contracts as contracts for work.

Since digital content and digital services are relatively new phenomena, ones not foreseeable when the provisions of the LOA were initially drafted, one could ask whether the fact that the object of a lease contract is restricted to being a thing in the meaning of the GPCCA should be considered to point to a gap in the law. If the most suitable type of contract for handling such supply under the LOA, or the closest analogue, is a lease contract, one then may ask whether this gap could be filled by analogy or, instead, the legislator should amend the law when transposing the Directive, to allow digital content to be deemed the object of a lease contract. The answer depends on the possibility of qualifying such contracts for the supply of digital content or services as other contract types under Estonian law. If other possibilities are available, there would be no need to apply the rules on lease contracts.

The analysis presented below is centred mainly on the characteristic obligations of the parties under lease contracts and contracts for work. The aim is to determine which of these two contract types is more suitable for regulating contracts for the supply of digital services. Thereby, the analysis should aid in determining whether it is necessary to apply the rules on lease contracts also in cases wherein the object of the contract is not a thing.

\section{Characteristic obligations of the parties to contracts for the supply of digital services}

\subsection{Obligations of the trader}

According to Section $271 \mathrm{LOA}$, the lessor is obliged to deliver a thing to the lessee. Subsection 276(1) LOA further specifies that the lessor is required to deliver a thing, together with its accessories, to the lessee by the agreed time and in suitable condition for use in accordance with the contract and also that the lessor must ensure that the thing is maintained in said condition throughout the duration of the contract. Under a contract for work, as is noted above, the contractor is obliged to achieve a certain result pursuant to Section 635 of the LOA.

With regard to using a cloud service or some other software on the Internet, the obligation to deliver the thing under a lease contract could, in theory, be translated as making it available for use - that is, rendering it accessible to the consumer in some way. The trader can keep the software in such condition that it can be used as agreed in the contract. However, considerable doubt remains as to whether these actions are characteristic of leasing or, rather more, some type of supply of services.

In the legal literature, the distinction between lease contracts and other contracts for the supply of services has been articulated on the basis of the objectives pursued by the parties. This has been assessed primarily with regard to traditional 'tangible' benefits, such as the use of machinery or automobiles together with personnel to operate them. If the choice of the automobile is what is most important and this is entirely determined by the customer, then the example represents a lease contract. If, however, the work owed by the other party and the achievement of a specific result are important, this is an example of a contract for work. ${ }^{*} 45$

In my view, the foregoing logic is difficult to transfer to the context of using Web-based software, and differentiating between the objectives may be somewhat artificial. This is because, while the consumer indeed

45 V Emmerich, C Rolfs, and B Weitemeyer (eds), J von Staudingers Kommentar zum Bürgerlichen Gesetzbuch mit Einführungsgesetz und Nebengesetzen, Buch 2, Recht der Schuldverhältnisse, ss 535-562d: 'Verordnung über Heizkostenabrechnung (Mietrecht I)' 15, marginal note 37; M Häublein in Münchener Kommentar Zum BGB (n 30) introductory note to s 535, marginal note 23 . 
has an opportunity to use the software, ensuring access to the software can simultaneously be viewed as a specific result derived from the trader's performance. The trader provides the consumer with access to the cloud service and maintains this accessibility for the consumer for the duration of the contract's validity. The obligation to maintain the thing requires a performance on the trader's part, which has a specific result in the form of maintaining the object of the contract in such a condition that it is suitable for use under the contract.

Although, as noted above, the German BGH has deemed ASP contracts to be lease contracts, it also has, on the other hand, applied the rules applicable to contracts for work to a contract that had as its substance creating a personal Web site for the customer and maintaining it on the Internet ${ }^{*} 46$. Such an obligation, by which the Web site must be accessible to third parties via the Internet under the usual conditions at all times, is an obligation under a contract for work. Unlike in the case of ASP contracts, this entails not merely providing access to a particular possibility for storing data; rather, what the trader promises to the consumer is in some sense a specific result. ${ }^{*} 7 \mathrm{I}$ agree that such contracts are likely to be contracts for work, yet comparing them to ASP contracts leads to the question of whether maintaining permanent access to a Web site is comparable to maintaining permanent access for the consumer to a cloud environment or a piece of Web-based software.

German legal literature has suggested that software-as-a-service contracts may indeed be oriented toward achievement of a specific result even though the contractor does not normally perform any work that is specific to the user, instead maintaining access to the cloud environment for the consumer only as a standardised act that is not normally active. ${ }^{*} 48$ The foregoing arguments are understandable, yet if these criteria are taken as a basis, a question naturally arises as to whether contracts involving streaming (as with Spotify or Netflix) could be considered to fall under work contracts versus lease contracts. Under such contracts, access to specific music or other content is ensured for consumers in a particular geographical area, and making a particular piece of music by a particular artist available to be played by the consumer on some device is likewise a rather standardised act. Yet contracts for streaming applications have been treated as contracts for work in the German literature ${ }^{*} 49$ and should be qualified as contracts for work under Estonian law too, in my opinion.

While, as was noted above, the possibility of entering into a lease contract for the supply of digital content and services is recognised under the prevailing view in Germany, this stance has been criticised. For example, some critics have pointed out that the associated situation involves not just a temporally limited right to use a digital application but also the use of several services, by which various of the customer's economic objectives are fulfilled. ${ }^{*} 5$

In the Estonian legal literature meanwhile an opinion has been expressed that software-as-a-service contracts entail provision of a service with the assistance of software. Generally, the contract is for work such as word-processing, accounting services, storage and processing of data, or the like, although in any specific case the form might involve a lease contract, usufructuary lease contract, or mixed contract. ${ }^{*}{ }^{1}$ Thus, the definitive qualification of such contracts is left open, although the authors appear to lean toward favouring the application of rules governing contracts for work.

Analysis of the trader's obligations reveals that qualifying these obligations under either a contract for lease or one for work is not clear-cut. The performance of the trader could, in principle, be viewed both as allowing the consumer to use software and as providing a service with a specific result. I tend to see this more as providing a service, for the reasons outlined above. To examine the possible qualification of contracts for the supply of digital services in greater depth, one must assess the obligations of the consumer as well.

\footnotetext{
Internet-System-Vertrag in German.

[2010] NJW 1449, 'BGH Qualifizierung eines Internet-System-Vertrags als Werkvertrag'.

'Bericht Der Arbeitsgruppe „Digitaler Neustart“' (n 25) 143.

Schmidt-Kessel and others (n 18) 62.

Kirn and Müller-Hengstenberg (n 26) 435.

Kalamees and others (n 8) 259.
} 


\subsection{Obligations of the consumer}

Under Section 271 LOA, the lessee undertakes to pay a fee to the lessor. Under Subsection 276(2), the lessee is obliged also to use the thing with care and in accordance with the intended purpose that forms the basis for the lease. The obligation of the lessee to return the thing to the lessor upon expiry of the contract is set out in Subsection 334(1) of the LOA.

Paying a fee or using the object of the contract with care in accordance with its intended purpose are not problematic for the contract's qualification as a lease contract. What is problematic is application of the rules that are to be applied upon expiry of the term of contract. Under Section 334 LOA, the lessee must return the thing to the lessor upon expiry of the contract's validity. The commentary to the Law of Obligations Act specifies that this is one of the main obligations of the lessee. ${ }^{*}{ }^{2}$ In addition, there are rules specifying the condition in which the thing must be returned. No such moment comes to pass, however, when one is using a cloud service, as the server space as such is not returned. At some point, the consumer loses access to storage space in the cloud or to a computer program hosted in the cloud, but the consumer does not perform any act, he does not vacate any premises, and he does not return anything to the lessor in a manner that would be comparable to a transfer of possession of a thing. Consequently, the rules set forth in Section 334 on the condition of the thing being returned and the accompanying liability, due to their nature, would not be applicable. In consequence, these issues, which are of such great importance in leasing of a corporeal thing and which can give rise to a number of problems in practice ${ }^{*}$, are not at all characteristic of digital services. This aspect of the matter is bound up with the question analysed above, of what can be the object of a lease contract.

In the case of contracts for work, in turn, the main obligation of the customer under Section 635 LOA is to pay remuneration for the work. This does not pose a problem with regard to qualifying the contract at issue as a contract for work. The remaining obligations of the customer, such as those under Section 638 (the obligation to accept the work) and Section 652 (the obligation of the contractor to co-operate as necessary for performance of the contract), are accessory obligations. ${ }^{*} 54$ They pose no obstacles to qualifying the supply of digital services as carried out under a contract for work.

Therefore, one can conclude that problems in assessing the obligations of the consumer in the context considered here arise with lease contracts but not with contracts for work.

\subsection{Supply of digital services as a continuing obligation}

Digital services can be supplied through a single act of supply in the meaning of Article 11(2) of the Directive, with one example being the translation of a document by means of an online software application. ${ }^{*} 5$ Many digital services, however, primarily involve continuous supply over some span of time in the sense of Article 11(3) of the Directive, on the basis of which the trader is liable for a lack of conformity that occurs or becomes apparent within the period of time during which the digital content or digital service is to be supplied under the contract. Contracts for cloud services and software as a service are among those that involve continuing obligations.

Contracts for the supply of cloud services or other, similar digital services could therefore be easily qualified as lease contracts, since lease contracts involve continuing obligations ${ }^{*}{ }^{*}$. In contrast, the qualification of contracts for the supply of digital services that entail continuous or repeated supply as contracts for work is more complicated in this respect.

In both Estonian and German legal literature, the opinion has been expressed that, since a contract for work is concluded for the purpose of achieving a result ${ }^{*} 57$ and although performance under a contract for work may continue over an extended time, the underlying relationship does not normally involve a

52 Varul and others, Võlaõigusseadus II, Kommenteeritud Väljaanne (n 8) 237.

53 For example, when a lessee fails to vacate a leased flat after the contract ends.

54 Varul and others, Võlaõigusseadus III Kommenteeritud Väljaanne (n 34) 39.

55 C Wendehorst in J Stabentheier, C Wendehorst, and B Zöchling-Jud (eds), Das Neue Europäische Gewährleistungsrecht - Zu Den Richtlinien (EU) 2019/771 Über Den Warenkauf Sowie (EU) 2019/770 Über Digitale Inhalte Und Digitale Dienstleistungen (Manz 2019) 115.

56 Varul and others, Võlaõigusseadus II, Kommenteeritud Väljaanne (n 8) 236.

57 Varul and others in Võlaõigusseadus III Kommenteeritud Väljaanne (n 34$) 35$. 
continuing obligation. ${ }^{*}{ }^{8}$ This is only a general rule, however. In contrast, the commentary on the Estonian Law of Obligations Act points to the example of a contract for work as creating a continuing obligation when a trader orders a service for maintenance of hardware and software used in that trader's business from a third party. Here, the conforming result is the smooth operation of the hardware and software for the trader's business activities. ${ }^{*} 99$ Also, a German commentary expresses the view that the determining factor in qualifying a contract as a contract for work is not whether an act under the contract should be performed once, which would indicate a contract for work, as opposed to continuously, which would indicate a contract for services. Such a distinction is not provided for in Section 631 BGB and therefore cannot serve as the basis for distinguishing between distinct types of contracts. ${ }^{*} 60$

In my view, contracts for work can involve continuing obligations. Electronic-communications contracts or contracts for daily cleaning services would also be appropriate examples here. Consequently, the continuous nature of certain digital services, among them the provision of cloud services, should not rule out the qualification of any specific contract as a contract for work under Estonian law.

\section{Conclusion}

This article presented an analysis of the qualification of contracts for the supply of digital content and digital services under Estonian law. Particular focus was placed on cloud services contracts and software as a service contracts.

As the object of a lease contract has to be a thing, concluding a lease contract is certainly a possible form for the supply of digital content or digital services where the digital content is stored on some physical medium and this medium is delivered to the consumer under the lease contract. Furthermore, German court practice qualifies cloud-services contracts as lease contracts even if no thing is delivered, as long as the software is stored somewhere on some physical medium. To my knowledge, no similar court practice exists in Estonia, and, therefore, the question arises of whether granting use of a thing could also be interpreted so broadly under Estonian law. It is my opinion that the benefit the consumer receives under such a contract is not the use of a thing and the connection to an actual physical thing (for example, a server) cannot be so remote.

In the case of a usufructuary lease contract, the object of the contract can be an incorporeal object. Yet another distinguishing characteristic of a usufructuary lease contract, under Estonian law and under German law as well, remains: the element of obtaining fruit. This requirement excludes the possibility of qualifying such contracts as usufructuary lease contracts.

The supply of digital content and digital services, including the provision of cloud services, is normally oriented toward achievement of a result. This orientation is characteristic of contracts for work; therefore, contracts for the supply of digital services should be qualified as contracts for work rather than contracts for services, in practice. Said qualification is not precluded by the continuous supply of digital services, as contracts for work may well involve continuing obligations. Likewise, this conclusion should not be affected by the fact that providing the digital service may be linked also to actions of third parties, such as the consumer's Internet service provider.

Whether the obligations of the trader are rather more characteristic of work or of lease is difficult to ascertain precisely. On the one hand, the consumer has the opportunity to use software, but, on the other hand, the obligation to ensure continuous access can be seen as a specific result that is dependent on the actions of the trader. At the same time, unlike in the case of lease contracts, when one applies the rules pertaining to contracts for work, the supply of digital content or digital services presents no difficulties related to the object of the contract or in relation to subjecting the obligations of the consumer to the rules on contracts for work. Therefore, cloud-services contracts and software-as-a-service contracts should be qualified as contracts for work, not as leasing contracts, under Estonian law. Accordingly, there is no need to apply the rules on lease contracts by way of analogy.

\footnotetext{
Busche in Münchener Kommentar Zum BGB 8. Auflage 2020 (n 30) s 631, marginal note 1.

Varul and others in Võlaõigusseadus III Kommenteeritud Väljaanne (n 34) 37.

Mansel in Jauernig Bürgerliches Gesetzbuch Kommentar (n 35) s 631 (preliminary remark), marginal note 3.
} 